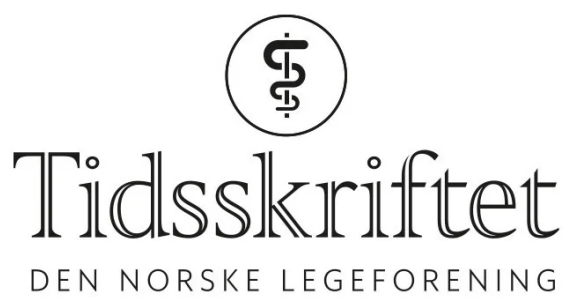

\title{
Lojalitet versus lydighet
}

AKTUELT I FORENINGEN

ANNE-KARIN RIME

anne.karin.rime@legeforeningen.no

President

Helsetjenesten trenger ledere som tør å si ifra når budsjettene ikke er forenelig med et godt og forsvarlig helsetilbud. 


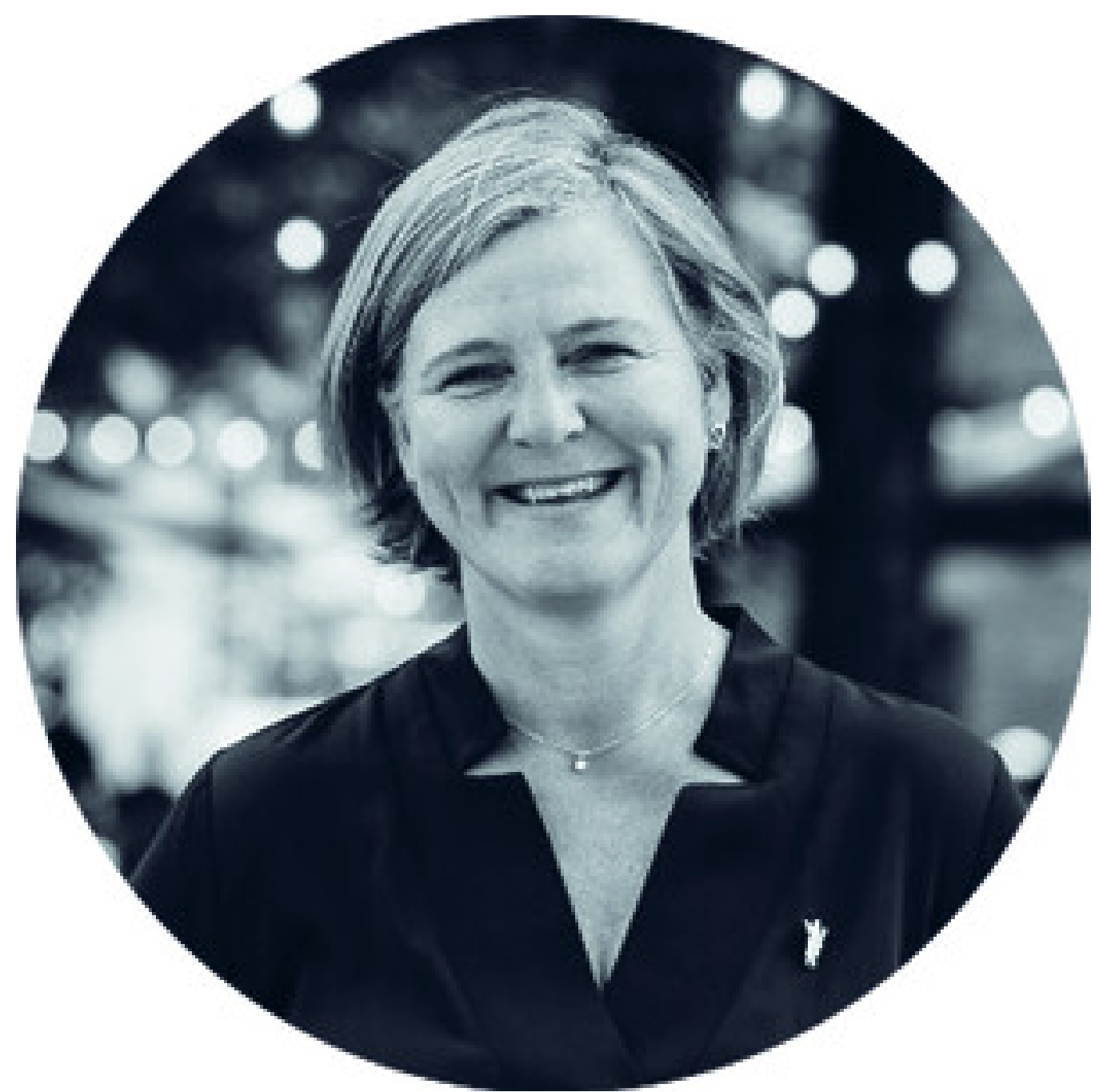

De siste dagene jeg var leder for Overlegeforeningen, arrangerte vi et utsatt jubileumskurs i anledning foreningens 6o-årsdag. Forsvarssjef Eirik Kristoffersen var invitert til å innlede på kurset. Han holdt et engasjerende innlegg om ledelse.

I et intervju til NRK i fjor var Kristoffersen tydelig på følgende: «Jeg vil ikke ha lydighet. Lydige folk er farlige. Jeg vil ha lojalitet. Folk som tør å si ifra når de føler at noe er galt, at sikkerheten ikke tas alvorlig nok eller vi beveger oss i etiske gråsoner. Det er de som er lojale. Det er sånne folk jeg satser på.»

Slike ledere ønsker jeg meg i helsetjenesten også. De som tør å si ifra når budsjettet ikke henger sammen med ansvaret for at alle skal få et forsvarlig og likeverdig helsetilbud uansett hvor de bor, det såkalte «sørge-for-ansvaret». Mange gjør dette allerede, men føler samtidig på at de ikke får gjennomslag fordi økonomien er det viktigste de blir målt på. Altfor ofte taper faglig kvalitet terreng mot bunnlinjen.

Jeg ønsker at alle ledere, helt opp til helseministeren, sier ifra når tjenesten er for hardt presset - og hvordan tjenesten kan bli bedre med noe mer økonomisk armslag. Både regjering og opposisjon må ta ansvar for at budsjettene er store nok til å innfri alle kravene og forventningene politikerne og befolkningen stiller til helsetjenesten.

Dyktige lederkolleger står hver dag i spennet mellom tilbud og ressurser, personalansvar og medisinsk ansvar, eller innkjøp av utstyr og personalmangel. Dette er utfordrende, til tross for at leger har gode forutsetninger for å klare oppgaven godt. Men ledere er helt avhengige av tilstrekkelige rammer og deretter ha reell mulighet til å prioritere innenfor disse rammene. Da legger vi til rette for god ledelse - og ikke bare administrasjon.

Mange leger velger å fortsette å jobbe noe klinisk når de går over i lederstilling. Det kan være bra i mange tilfeller. Det gir legitimitet både oppover og nedover i systemet. Men ledelse må ikke bli venstrehåndsarbeid, fordi det er viktig at legen bruker nok tid på å 
faktisk være leder. Derfor er mer avlastende støttepersonell helt vesentlig.

Både Allmennlegeforeningen, Yngre legers forening og Overlegeforeningen har egne stipender for leger som ønsker å ta lederutdanning. Disse kan man lese mer om på Legeforeningens nettsider. Jeg oppfordrer alle som er interessert til å søke.

I 2018 startet Legeforeningen et pilotprosjekt i samarbeid med Universitet i Oslo: Helselederskolen. Dette er en lederutdanning som gir studiepoeng og er ment å være en tidlig introduksjon til ledelse for unge leger. De som har gjennomført kursene har gitt gode tilbakemeldinger. Prosjektet skal evalueres etter årets kull.

Kort oppsummert, Legeforeningen har gjennom årene hatt ulike former for lederutvikling. Dette $\emptyset$ nsker vi å fortsette med i fremtiden. For vi trenger nemlig engasjerte ledere som tør å si ifra-ledere som er lojale mot samfunnsoppdraget.

Publisert: 25. oktober 2021. Tidsskr Nor Legeforen. DOI: 10.4045/tidsskr.21.15.11

(C) Tidsskrift for Den norske legeforening 2023. Lastet ned fra tidsskriftet.no 26. april 2023. 